\title{
DESORPTION OF $\beta$-CAROTENE FROM BENTONITE ADSORBENT UNDER MICROWAVE IRRADIATION
}

\author{
Tatjana Novaković ${ }^{1}$, Ljiljana Rožić ${ }^{1 *}$, Srdjan Petrović ${ }^{1}$, Dragomir Stanisavljev ${ }^{2}$ \\ ${ }^{1}$ University of Belgrade, Institute of Chemistry, Technology and Metallurgy, Department of Catalysis \\ and Chemical Engineering, Njegoševa 12, Belgrade, Republic of Serbia \\ ${ }^{2}$ University of Belgrade, Faculty of Physical Chemistry, Studentski trg 12-16, Belgrade, Republic of Serbia
}

ljrozic@ nanosys.ihtm.bg.ac.rs

\begin{abstract}
The desorption behavior of $\beta$-carotene from a bentonite adsorbent under microwave irradiation in isopropanol was studied as a function of temperature and different initial loading concentrations. A firstorder, two-component, three-parameter model described the desorption kinetics with a coefficient of determination $R^{2}>0.9932$, and the $\beta$-carotene desorption process under microwave irradiation was controlled by both rapid and slow desorption. The activation energies of $\beta$-carotene desorption for the rapid and slow desorption processes were 19.61 and $53.04 \mathrm{~kJ} \mathrm{~mol}^{-1}$, respectively. It was observed that the desorption equilibrium data fitted well to both the Freundlich and Langmuir isotherms. The data obtained from the desorption-isotherm model were used to determine the thermodynamic parameters. The positive value of free energy indicates the non-spontaneity of $\beta$-carotene desorption. The change in entropy relative to the enthalpy of desorption reveals that the reaction is physical in nature.
\end{abstract}

Keywords: $\beta$-carotene; desorption; bentonite; microwave irradiation; kinetics

\section{ДЕСОРПЦИЈА НА $\beta$-КАРОТЕН ОД БЕНТОНИТСКИ АТСОРБЕНТ ВО УСЛОВИ НА МИКРОБРАНОВА ИРАДИЈАЦИЈА}

\begin{abstract}
Десорпциското однесување на $\beta$-каротенот од бентонитски атсорбент беше истражувано во услови на микробранова ирадијација како функција на температурата и различни концентрации на полнењето. Кинтетички двокомпонентен модел од прв ред со три параметри ја опишува десорпциската кинетика со коефицинет на корелација $R^{2}>0.9932$. Десорпцискиот процес на $\beta$ каротенот во услови на микробранова ирадијација е контролиран и со брза и со бавна десорпција. Активациските енергии на десорпцијата на $\beta$-каротенот за брзата и за бавната десорпција соодветно изнесуваат $19,61 \mathrm{~kJ} \mathrm{~mol}^{-1}$ и $53,04 \mathrm{~kJ} \mathrm{~mol}^{-1}$. Забележано е дека десорпциската рамнотежа добро се вклопува во изотермите на Freundlich и на Langmuir. Добиените податоци на моделот на десорпциската изотерма се употребени за определување на термодинамички параметри. Позитивната вредност на слободната енергија укажува на неспонтаност на десорпцијата на $\beta$ каротенот. Промената на ентропијата во однос на енталпијата укажува дека десопцијата по природа е физичка.
\end{abstract}

Клучни зборови: $\beta$-каротен; десорпција; бентонит; микробранова ирадијација; кинетика

\section{INTRODUCTION}

$\beta$-Carotene is an important member of the carotenoid family of orange-colored pigments, which is widely used as an additive in the food industry $[1,2]$. For this reason, it is of great importance to examine the possibility of desorption of the colored pigments as well as the kinetics of 
the process. A number of adsorption/desorption processes involving the removal of colored pigments have been observed to exhibit biphasic behavior, with a rapidly desorbing phase followed by a fraction that desorbs more slowly. Most previous studies have focused on the removal of $\beta$-carotene and chlorophyll from various types of oils by acidactivated bentonite [3-9]. These studies reported that the rate of adsorption is controlled by mass transfer because the adsorption rate of $\beta$-carotene is very fast compared to the rate of its transfer from the bulk oil to the clay surface.

The first (fast) step of adsorption represents the chemical interaction between the acid centers on the bentonite surface and $\beta$-carotene, whereas the second (slow) step may indicate the physical adsorption of $\beta$-carotene onto the molecules that are adsorbed in the first step. The heterogeneity of the active centers explains the gradual increase in adsorption of $\beta$-carotene with increasing temperatures at different clay/oil ratios, because a proportion of these centers are activated at higher temperatures [3, 6]. The dependence of the adsorption/desorption rates on temperature is determined by the activation energy, which essentially describes how the chemical rate constants vary with temperature.

As edible oils contain a mixture of organic compounds (carotenoids, such as $\beta$-carotene and their derivatives, chlorophyll, tocopherols, and gossypol), fundamental studies on isolated molecules are scarce, and researchers tend to focus on the efficiency of the adsorption/desorption of compounds and the decrease in time and energy consumption $[7,9,10]$.

Only a few attempts have been made to describe the adsorption of $\beta$-carotene on acidactivated bentonite at low temperatures, using acetone, xylene, $n$-hexane, or isopropanol as solvents $[6,7,11,12]$. Muhammad et al. have shown that the adsorption of $\beta$-carotene using isopropanol is higher than using $n$-hexane as a solvent because of the low polarity index of $n$-hexane compared to isopropanol. Therefore, the stronger bond between $\beta$-carotene and $n$-hexane inhibits the transfer of carotene to the adsorbent [12].

Microwave heating is a widely accepted, nonconventional energy source for inorganic synthesis [13] and different physicochemical processes such as regeneration [14], extraction [15, 16], adsorption [17], and desorption [18]. The efficiency of microwave-based processes is not only reflected in the reduction in reaction time, it is also known to significantly accelerate the rate of chemical reactions and physicochemical processes, re- sult in higher yields and improve the properties of the products [19].

Although extensive studies on the effects of microwave heating various physicochemical processes have been reported, the influence of microwave heating on the desorption processes of $\beta$ carotene from bentonite adsorbents has not yet been investigated.

In this study, the effect of different experimental parameters, that is, the desorption temperature and various initial concentrations of $\beta$ carotene, on the fast- and slow-desorption processes induced by microwave heating were studied by performing simulations based on a kinetic model. A first-order, two-component, three-parameter model was applied to fit the experimental data. The kinetics and thermodynamic parameters, such as the Gibbs free energy, enthalpy, and entropy, were also calculated. These approaches provide greater insight into the characteristics of $\beta$-carotene desorption from acid-activated bentonite. The results help to understand the reaction mechanism of $\beta$ carotene during microwave heating and promote the application of $\beta$-carotene in the food industry.

\section{EXPERIMENTAL}

\subsection{Materials}

The results of our previous investigations on the modelling and optimization of bentonite activation through a response surface methodology [20] were applied to modify bentonite, which was used as the starting material in the current study. Acidactivated bentonite (AABent) obtained under these optimal conditions, with a particle size less than 75 $\mu \mathrm{m}(-200$ mesh ASTM), has an average chemical composition (\% by wt.) of $\mathrm{SiO}_{2} 73.66, \mathrm{Al}_{2} \mathrm{O}_{3} 12.28$, $\mathrm{Fe}_{2} \mathrm{O}_{3} 4.73, \mathrm{CaO} 0.70, \mathrm{MgO} 1.99, \mathrm{Na}_{2} \mathrm{O} 0.60, \mathrm{~K}_{2} \mathrm{O}$ 0.30 , and $\mathrm{TiO}_{2} 0.57$, as well as an ignition upon loss of 5.17. Mineralogical analysis confirmed that AABent consisted predominantly of smectite and contained a substantial amount of quartz impurities as well as minor amounts of feldspar. Anhydrous $o$ xylene, isopropanol, and $\beta$-carotene were purchased from Sigma-Aldrich (USA).

\subsection{Nitrogen adsorption}

The specific surface area, pore diameter, and total pore volume of the prepared AABent were measured by $\mathrm{N}_{2}$ adsorption-desorption isotherms obtained at $77 \mathrm{~K}$ using an automatic adsorption apparatus (Sorptomatic 1990 Thermo Finningen). The specific surface area of each sample was cal- 
culated by fitting the adsorption data to the linear range of the BET equation [relative to $p / p_{0}(0.05-$ $0.35)]$. The pore size distribution was calculated according to the $\mathrm{BJH}$ method using $\mathrm{N}_{2}$ desorption isotherms [21].

\subsection{Adsorption of $\beta$-carotene onto acid activated bentonite}

In a $250 \mathrm{ml}$ conical flask, AABent $(10 \mathrm{~g})$ was initially saturated with different concentrations $\left(389,581\right.$, and $\left.658 \mathrm{mg}^{-1}\right)$ of $\beta$-carotene solution in $o$-xylene. The saturation reaction was conducted in a temperature-controlled water-bath shaker at 338 $\mathrm{K}$ and $150 \mathrm{rpm}$ for $90 \mathrm{~min}$ in order to reach equilibrium [11]. To establish thermal equilibrium before adsorption, the flask containing the solution was agitated for $15 \mathrm{~min}$ in a water bath at the desired temperature, and the AABent was then added to the solution. After a predetermined amount of time, the samples were filtered immediately and the supernatant solution was analyzed using a UV/Vis spectrophotometer (Thermo Electron Corporation, Evolution 500). The absorbance of the $\beta$ carotene was measured before and after adsorption at a wavelength of $457 \mathrm{~nm}$. The absorbance values of $\beta$-carotene could be transformed to $\beta$-carotene concentrations using the calibration curve.

The obtained result, reported as the amount of $\beta$-carotene adsorbed per gram of AABent, was used as the initial concentration in the desorption experiments.

\subsection{Desorption of $\beta$-carotene under microwave irradiation}

Desorption of $\beta$-carotene from AABent saturated with different $\beta$-carotene concentrations $(3.89,5.81$, and $6.58 \mathrm{mg} \beta$-carotene per gram bentonite; denoted as samples 1,2 , and 3 , respectively) was carried out using a CEM-focused microwave reactor (Discovery, Corp. Matthews, North Carolina, US) with an adjustable power and con- tinuous microwave power output operated at 2.45 GHz. All experiments were performed in a cylindrical glass cell with diameter $d=9 \mathrm{~mm}$ and height $H=45 \mathrm{~mm}$. To maintain constant microwave irradiation and a constant temperature during the process, the temperature of the cell was externally controlled. The temperature of the solution was measured with a commercial fiber optic sensor. To measure the desorption kinetics, isopropanol solution $(10 \mathrm{ml})$ was added to a cylindrical glass cell and then heated in the microwave reactor at a constant microwave power of $80 \mathrm{~W}$. After reaching the required experimental temperature, AABent $(0.4 \mathrm{~g})$ with different $\beta$-carotene concentrations was placed in the cell. The samples were withdrawn at specified time intervals and analyzed using a UV/Vis spectrophotometer at $\lambda_{\max }=457 \mathrm{~nm}$. The amount of $\beta$-carotene remaining on the adsorbent, $q_{t}\left(\mathrm{mg} \mathrm{g}^{-1}\right)$, was calculated using the massbalance equation:

$$
q_{t}=q_{\mathrm{i}}-\frac{V\left(C_{t}-C_{\mathrm{i}}\right)}{m},
$$

where $q_{\mathrm{i}}$ is the initial solid-phase $\beta$-carotene concentration $\left(\mathrm{mg} \mathrm{g}^{-1}\right), C_{t}$ is the $\beta$-carotene concentration in solution $\left(\mathrm{mg} \mathrm{l}^{-1}\right)$ at any time, $C_{\mathrm{i}}$ is the initial $\beta$ carotene concentration in solution $\left(\mathrm{mg} \mathrm{l}^{-1}\right), V$ is the volume of the solution, and $m$ is the adsorbent mass.

\section{RESULTS AND DISCUSSION}

\subsection{Textural properties of bentonite adsorbents}

The textural properties of the as-prepared AABent and AABent with various initial $\beta$ carotene loading concentrations are presented in Table 1. Adsorption analysis revealed that all of the samples yielded type IV isotherms [21], which are indicative of mesoporous materials (Figure 1).

Table 1

Textural properties of bentonite adsorbents as a function of the initial loading concentration of $\beta$-carotene

\begin{tabular}{lcccc}
\hline Sample & $\begin{array}{c}\text { BET surface area } \\
\left(\mathbf{m}^{\mathbf{2}} \mathbf{g}^{-\mathbf{1}}\right)\end{array}$ & $\begin{array}{c}\text { Pore volume } \\
\left(\mathbf{c m}^{\mathbf{3}} \mathbf{g}^{\mathbf{- 1}}\right)\end{array}$ & $\begin{array}{c}\text { Micropore volume } \\
\left(\mathbf{c m}^{\mathbf{3}} \mathbf{g}^{\mathbf{- 1}}\right)\end{array}$ & $\begin{array}{c}\text { Pore diameter } \\
(\mathbf{n m})\end{array}$ \\
\hline AABent & 202 & 0.246 & 0.0913 & 3.71 \\
Sample 1 & 175 & 0.231 & 0.0659 & 3.62 \\
Sample 2 & 166 & 0.225 & 0.0634 & 3.64 \\
Sample 3 & 160 & 0.217 & 0.0604 & 3.62 \\
\hline
\end{tabular}


The general shape of the isotherms did not change after $\beta$-carotene adsorption; however, a slight decrease in the amount of adsorbed nitrogen was observed. All of the isotherms were reversible at a low equilibrium pressure. However, under high pressure, an $H 3$ hysteresis loop was observed [22], indicating that the pores were shaped as slits or ink bottles (pores with narrow necks and wide bodies).

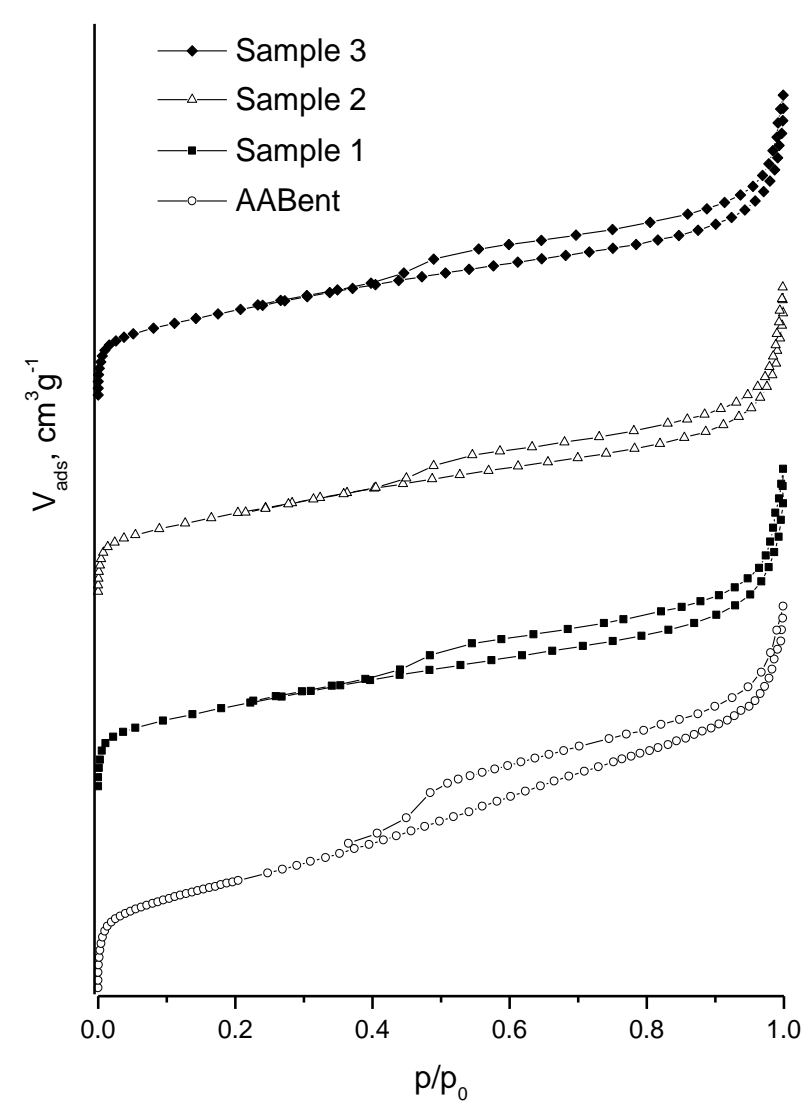

Fig. 1. Adsorption-desorption isotherms of samples 1, 2, and 3 as well as AABent

Comparison of the results (Table 1) shows that the specific surface area and the total pore volume decreased as the initial loading concentration of $\beta$-carotene increased. The micropore volumes of AABent and samples 1, 2, and 3 exhibited a behavior that was very similar to that of the total pore volume. However, the mean pore diameter remained constant, indicating that the preparation procedure did not alter the primary structure of the support. Thus, only partial filling of pores was observed, owing to the adsorption of $\beta$-carotene. Changes in the surface area, micropore volume, and pore volume indicate that the adsorption may have occurred on the external surface, as there is no change in pore diameter.

\subsection{Desorption profile}

The extent of $\beta$-carotene desorption from samples 1, 2, and 3 under microwave irradiation was studied as a function of time under different conditions, that is, with different initial $\beta$-carotene concentrations and desorption temperatures. The $\beta$ carotene desorption profiles were similar for all of the systems (Fig. 2 and Fig. 3).

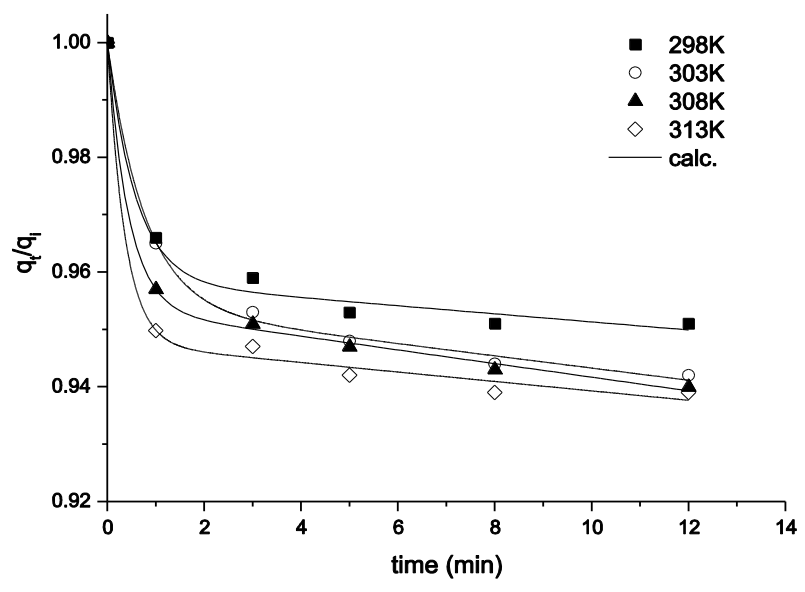

Fig. 2. Desorption profile of $\beta$-carotene as a function of the contact time at various desorption temperatures

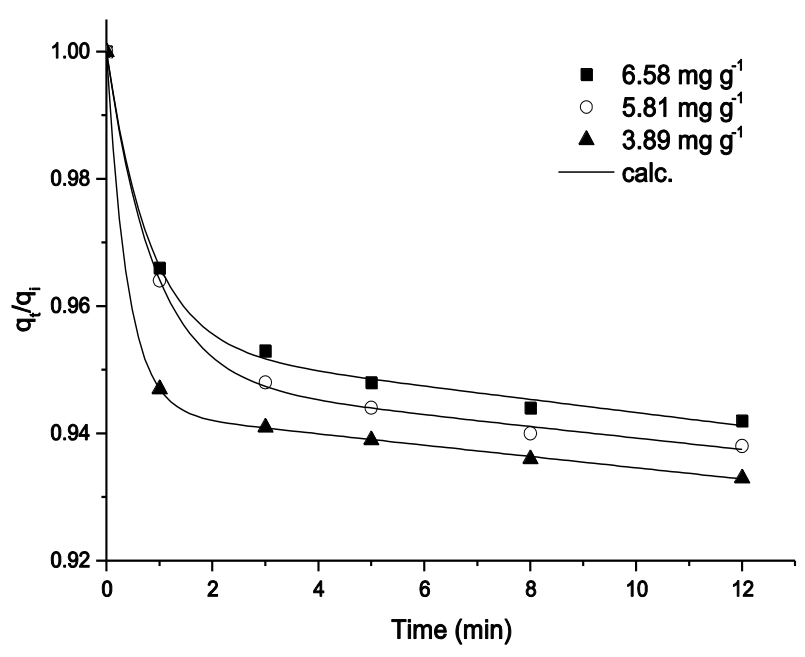

Fig. 3. Desorption profile of $\beta$-carotene as a function of the contact time at various initial loading concentrations

$\beta$-Carotene was desorbed rapidly during the early stages, which was followed by much slower release. The obtained results demonstrate that the initial, rapid desorption process that occurred over 1-3 min depends on both the temperature and the initial $\beta$-carotene concentration. The slow desorption process was the rate-limiting step for the recovery of $\beta$-carotene. As shown in Figure 1, an increase in the desorption temperature resulted in an increase in the $\beta$-carotene desorption rate and 
recovery, indicating that desorption of $\beta$-carotene from samples 1, 2, and 3 under microwave irradiation was also an endothermic process.

The desorption profiles of $\beta$-carotene from AABent at various initial concentrations (Fig. 3) reveal that increasing the concentration of $\beta$ carotene leads to a decrease in the $\beta$-carotene desorption rate.

\subsection{Desorption kinetics}

A first-order, two-component, three-parameter model was used to predict the $\beta$-carotene desorption kinetics. The model developed by Johnson and Weber [23] is defined as follows:

$$
\frac{q_{t}}{q_{\mathrm{i}}}=\Phi_{\mathrm{s}} e^{\left(-k_{\mathrm{s}} t\right)}+\left(1-\Phi_{\mathrm{s}}\right) e^{\left(-k_{\mathrm{r}} t\right)}
$$

were $\Phi_{\mathrm{S}}$ is the slowly desorbing fraction, $\left(1-\Phi_{\mathrm{S}}\right)$ is the rapidly desorbing fraction, and $k_{\mathrm{S}}$ and $k_{\mathrm{r}}\left(\mathrm{min}^{-1}\right)$ are the rate constants of slow and rapid desorption, respectively. This model was fitted to desorption kinetics data using the non-linear regression method. The values of $k_{\mathrm{S}}, k_{\mathrm{r}}$, and $\Phi_{\mathrm{S}}$ were obtained by minimizing the sum of the squares of the differences between the experimental and calculated values of $q_{t} / q_{\mathrm{i}}$. The parameters obtained from the model are useful for distinguishing between the rapidly and slowly desorbing fractions. This model does not necessarily have a physical meaning, that is, it is uncertain whether the rapid and slow desorption processes correspond to physicochemical processes. The desorption parameters obtained from the model are shown in Table 2.

Table 2

Desorption rate parameters for $\beta$-carotene as a function of temperature at an initial loading of $6.58 \mathrm{mg} \mathrm{g}^{-1}$ and as a function of the initial loading at $303 \mathrm{~K}$

\begin{tabular}{lccccc}
\hline & $\boldsymbol{\Phi}_{\mathbf{S}}$ & $\boldsymbol{k}_{\mathbf{r}}\left(\mathbf{m i n}^{-\mathbf{1}}\right)$ & $\boldsymbol{k}_{\mathbf{S}}\left(\mathbf{m i n}^{\mathbf{- 1}}\right)$ & $\boldsymbol{R}^{\mathbf{2}}$ & $\mathbf{S S E}$ \\
\hline Temperature (K) & & & & & \\
298 & 0.9558 & 1.7170 & 0.00074 & 0.9959 & $2.810^{-5}$ \\
303 & 0.9535 & 1.8197 & 0.00112 & 0.9965 & $5.110^{-6}$ \\
308 & 0.9536 & 2.3029 & 0.00155 & 0.9981 & $2.910^{-6}$ \\
313 & 0.9475 & 2.6955 & 0.00280 & 0.9932 & $1.110^{-5}$ \\
Initial loading conc. $\left(\mathbf{m g ~ g}^{-\mathbf{1}}\right)$ & & & & & \\
3.89 & & & & & \\
5.81 & 0.9435 & 2.5495 & 0.00110 & 0.9999 & $1.910^{-7}$ \\
6.58 & 0.9483 & 1.1248 & 0.00096 & 0.9989 & $1.910^{-6}$ \\
& 0.9536 & 1.2160 & 0.00094 & 0.9969 & $4.510^{-6}$ \\
\hline
\end{tabular}

It was observed that the model fitted the experimental data well, with a high coefficient of determination, $R^{2}$, greater than 0.9932. Also, the residual sum of squares (SSE) is a measurement of the discrepancy between the data and the estimation model. The very small SSE value shows that the experimental value was reasonably close to the predicted value.

Both the rapid and slow desorption rates and the slow desorption fraction were strong functions of desorption temperature and the initial loading concentration. The results show that, when the temperature increased from 298 to $313 \mathrm{~K}$, the $k_{\mathrm{S}}$ and $k_{\mathrm{r}}$ values increased from 0.000739 to 0.00280 $\mathrm{min}^{-1}$ and from 1.717 to $2.695 \mathrm{~min}^{-1}$, respectively. On the other hand, when the initial $\beta$-carotene loading concentration was increased, the desorption was slow and the $k_{\mathrm{S}}$ and $k_{\mathrm{r}}$ values decreased from 0.0011 to $0.00094 \mathrm{~min}^{-1}$ and from 2.549 to $1.216 \mathrm{~min}^{-1}$, respectively. An increase in the de- sorption temperature resulted in a decrease in the values of $\Phi_{\mathrm{S}}$, whereas increasing the initial concentration of $\beta$-carotene at $303 \mathrm{~K}$ is proportional to the change in $\Phi_{\mathrm{S}}$.

\subsection{Arrhenius plot}

The temperature dependence of the desorption rates of the rapidly and slowly desorbing $\beta$ carotene fractions can be described by an Arrhenius relationship [9, 23]:

$$
k_{\mathrm{r}} \text { or } k_{\mathrm{s}}=k_{0} \exp \left(-\frac{E_{\mathrm{des}}}{R T}\right) \text {, }
$$

where $k_{0}$ is the Arrhenius pre-exponential factor, $E_{\text {des }}$ is the apparent activation energy of the desorption process $\left(\mathrm{kJ} \mathrm{mol}^{-1}\right), R$ is the universal gas constant $\left(8.31 \mathrm{~J} \mathrm{~mol}^{-1} \mathrm{~K}^{-1}\right)$, and $T$ is the desorption temperature $(\mathrm{K})$. 
The equation can be rearranged as follows:

$$
\log k_{r} \text { or } \log k_{\mathrm{s}}=\log k_{0}-\frac{E_{\mathrm{des}}}{2.303 R T} \text {. }
$$

The activation energies of $\beta$-carotene desorption for both the rapid and slow processes were calculated from the slope of the plot of $\log k_{\mathrm{r}}$ or $\log k_{\mathrm{S}}$ versus $1 / T$ (Fig. 4).

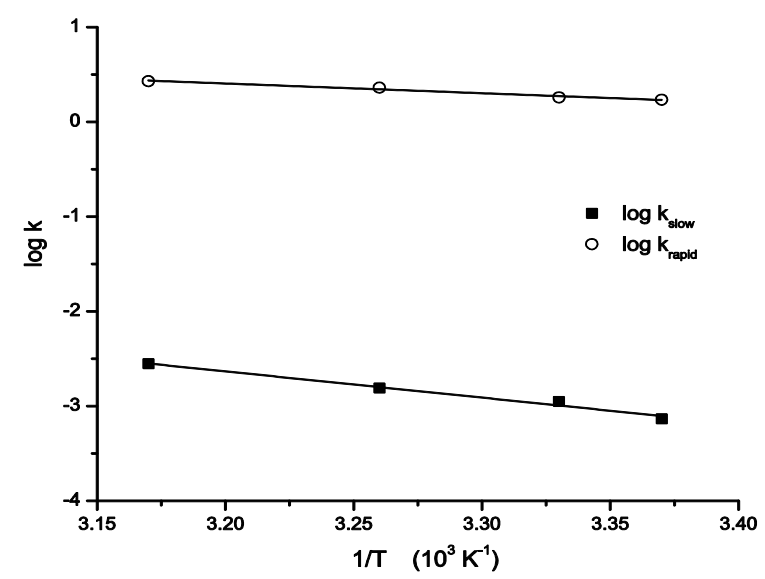

Fig. 4. Arrhenius relationships between temperature and the rate constants of the rapid and slow desorption processes of $\beta$ carotene from $\mathrm{AABent}$ with different loading concentrations

The values of $E_{\text {des }}$ obtained for the rapid and slow desorption processes were 19.61 and $53.04 \mathrm{~kJ}$ $\mathrm{mol}^{-1}$, respectively. These activation energy values are mainly for physical desorption mechanisms, and the whole desorption process could be finally controlled by diffusion. A higher activation energy was observed for the slow rate constant, confirming that diffusion may have occurred through the mesopores with smaller pore diameters. The activation energies obtained are higher than those calculated by Muhammad et al. [9] $\left(E_{\text {des, rapid }}=7.88 \mathrm{~kJ}\right.$ $\mathrm{mol}^{-1}$ and $E_{\text {des,slow }}=44.47 \mathrm{~kJ} \mathrm{~mol}^{-1}$ ) for $\beta$-carotene desorption from a mesoporous carbon-coated monolith in the temperature range $303-323 \mathrm{~K}$. However, the observed difference can be explained by the different experimental conditions used (microwave irradiation) and the properties of the adsorbent.

\subsection{Desorption isotherms}

The desorption equilibrium data were fitted to the Freundlich and Langmuir models. The wellknown logarithmic form of the Freundlich isotherm is expressed as follows:

$$
\log q_{e}=\log K_{\mathrm{F}}+\frac{1}{n} \log C_{e},
$$

where $q_{e}$ is equilibrium solid-phase $\beta$-carotene concentration, $C_{e}$ is equilibrium $\beta$-carotene concentration in solution, $K_{\mathrm{F}}$ and $n$ are Freundlich constants, with $n$ indicating how favorable the adsorption process will be and $K_{\mathrm{F}}\left(\mathrm{mg}\left[\mathrm{g}\left(\mathrm{L} \mathrm{mg}^{-1}\right)^{1 / n}\right]^{-1}\right)$ representing the adsorption capacity of the adsorbent. $K_{\mathrm{F}}$ can be defined as the adsorption or distribution coefficient and represents the quantity of $\beta$ carotene adsorbed onto AABent for a unit equilibrium concentration. The slope of $1 / n$, which ranges between 0 and 1 , is a measure of the adsorption intensity or surface heterogeneity, where values close to 0 indicate high heterogeneity [24]. A value of $1 / n$ below 1 indicates a normal Langmuir isotherm, whereas $1 / n$ values above 1 are indicative of cooperative adsorption. The plot of $\log q_{\mathrm{e}}$ versus $\log C_{\mathrm{e}}$ yields a straight line with a slope of $1 / n$ and an intercept of $\log K_{\mathrm{F}}$

The Langmuir model assumes that the surface of an adsorbent is homogeneous and that the adsorption energy is uniform for each adsorption site and solute uptake occurs by monolayer adsorption. A linearized form of the Langmuir isotherm is expressed as follows:

$$
\frac{C_{\mathrm{e}}}{q_{\mathrm{e}}}=\left(\frac{1}{K_{\mathrm{L}} b}\right)+\left(\frac{1}{b}\right)\left(C_{\mathrm{e}}\right)
$$

where $K_{\mathrm{L}}$ is the Langmuir equilibrium constant (L $\mathrm{mg}^{-1}$ ) and $b$ is the monolayer capacity of the adsorbent $\left(\mathrm{mg} \mathrm{g}^{-1}\right)$. The constants can be calculated from the slope and intercept of the straight line formed by plotting $C_{\mathrm{e}} / q_{\mathrm{e}}$ versus $C_{\mathrm{e}}$. The essential characteristics of the Langmuir isotherm can be expressed by a dimensionless constant called the separation factor, or equilibrium parameter, $R_{L}$, defined by Weber and Chakkravorti [25] as follows:

$$
R_{\mathrm{L}}=\frac{1}{1+K_{\mathrm{L}} C_{0}},
$$

where $C_{0}$ is the highest $\beta$-carotene concentration $\left(\mathrm{mg} \mathrm{l}^{-1}\right)$. The value of $R_{\mathrm{L}}$ indicates the type of isotherm that describes the desorption process: favorable $\left(0<R_{\mathrm{L}}<1\right)$, unfavorable $\left(R_{\mathrm{L}}>1\right)$, linear $\left(R_{\mathrm{L}}=1\right)$, or irreversible $\left(R_{\mathrm{L}}=0\right)$ [26].

The desorption parameters obtained from the regression of the curves after applying both desorption isotherms in the forms of Equations 3 and 4 are listed in Table 3. 
Table 3

Freundlich and Langmuir isotherm parameters for desorption of $\beta$-carotene from bentonite adsorbents under microwave irradiation

\begin{tabular}{|c|c|c|c|c|c|c|c|}
\hline \multirow{2}{*}{$\begin{array}{l}\text { Desorption system } \\
\text { Temperature }(\mathbf{K}) \\
\end{array}$} & \multicolumn{4}{|c|}{ Langmuir model } & \multicolumn{3}{|c|}{ Freundlich model } \\
\hline & $\begin{array}{c}b \\
\left(\mathrm{mg} \mathrm{g}^{-1}\right)\end{array}$ & $\begin{array}{c}K_{\mathrm{L}} \\
\left(\mathrm{L} \mathrm{mg}^{-1}\right) \\
\end{array}$ & $R^{2}$ & $\boldsymbol{R}_{\mathrm{L}}$ & $\begin{array}{c}K_{\mathrm{F}} \\
\left(\mathrm{mg}\left[\mathrm{g}(\mathrm{L} / \mathrm{mg})^{1 / \mathrm{n}}\right]^{-1}\right)\end{array}$ & $1 / n$ & $R^{2}$ \\
\hline 303 & 26.00 & 0.021 & 0.989 & 0.76 & 0.675 & 0.813 & 0.999 \\
\hline 308 & 16.76 & 0.038 & 0.995 & 0.65 & 0.742 & 0.800 & 0.993 \\
\hline 313 & 10.80 & 0.077 & 0.974 & 0.44 & 1.309 & 0.546 & 0.992 \\
\hline
\end{tabular}

The Freundlich and Langmuir models yielded high $R^{2}$ values, which were greater than 0.97 at all three temperatures studied, demonstrating that the desorption of $\beta$-carotene from a bentonite adsorbent can be described by these two models. For all of the desorption systems, the experimental data were observed to fit the Freundlich model better than the Langmuir model, as indicated by the higher $R^{2}$ values of the former. The relatively high non-linearity of the desorption isotherm may be attributed to the heterogeneity of the adsorption sites on the AABent surface [6], which suggests that some heterogeneity on the surface, or pores of the bentonite adsorbent, played a role in $\beta$-carotene desorption.

\subsection{Desorption thermodynamics}

The thermodynamic parameters that must be considered to evaluate desorption processes, such as changes in enthalpy $(\Delta H)$, entropy $(\Delta S)$, and Gibbs free energy $(\Delta G)$, were determined using data obtained from the Langmuir isotherm. The values of $\Delta H$ and $\Delta S$ can be computed using the following equation:

$$
\ln K_{\mathrm{L}}=\frac{\Delta S}{R}-\frac{\Delta H}{R T},
$$

where $R\left(8.314 \mathrm{~J} \mathrm{~mol}^{-1} \mathrm{~K}^{-1}\right)$ is the universal gas constant, $T(\mathrm{~K})$ is the absolute desorption temperature, and $K_{\mathrm{L}}\left(\mathrm{L} \mathrm{mg}^{-1}\right)$ is the Langmuir isotherm constant. The values of $\Delta H$ and $\Delta S$ can be calculated from the slope and intercept, respectively, of the van't Hoff plot of $\ln K_{\mathrm{L}}$ versus $1 / T$ (Fig. 5).

Table 4

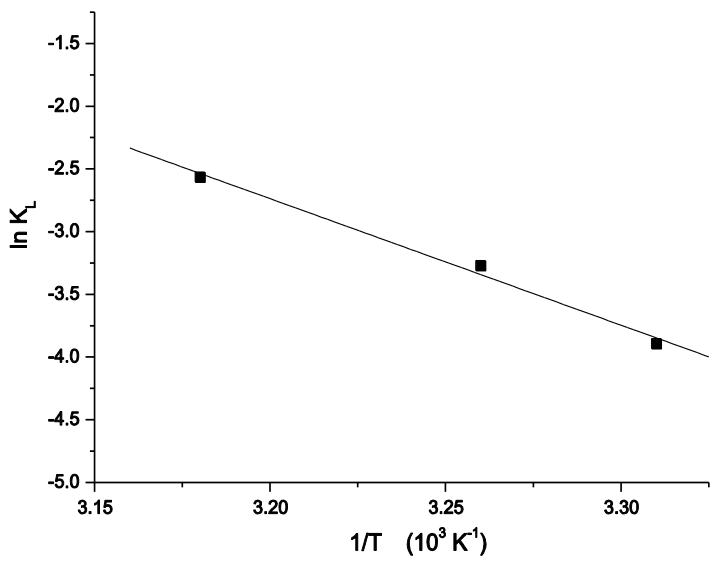

Fig. 5. Plot of $\ln K_{\mathrm{L}}$ versus $1 / T$ used to estimate the thermodynamic parameters of $\beta$-carotene desorption from AABent with different loading concentrations

The Gibbs free energy can then be calculated using the following relation:

$$
\Delta G=-R T \ln K_{\mathrm{L}} .
$$

The thermodynamic parameters were determined by considering desorption of $\beta$-carotene from samples 1,2 , and 3 under microwave irradiation at 303,308 , and $313 \mathrm{~K}$; the results are presented in Table 4.

The obtained values of $\Delta G$ were positive, which suggests that $\beta$-carotene desorption is a nonspontaneous process. The low $\Delta G$ values obtained indicate that the mechanism of desorption may involve both a chemical and a physical process.

Thermodynamic parameters for desorption of $\beta$-carotene from bentonite adsorbents

\begin{tabular}{|c|c|c|c|c|c|c|}
\hline \multirow{2}{*}{$\begin{array}{l}\Delta H \\
\left(\mathrm{~kJ} \mathrm{~mol}^{-1}\right)\end{array}$} & \multirow{2}{*}{$\begin{array}{l}\Delta S \\
\left(\mathrm{~J} \mathrm{~mol}^{-1} \mathrm{~K}^{-1}\right)\end{array}$} & \multirow{2}{*}{$\begin{array}{l}E_{\text {des slow }} \\
\left(\mathbf{k J ~ m o l}^{-\mathbf{1}}\right)\end{array}$} & \multirow{2}{*}{$\begin{array}{l}E_{\text {des rapid }} \\
\left(\mathrm{kJ} \mathrm{mol}^{-1}\right)\end{array}$} & \multicolumn{3}{|c|}{$\Delta G\left(\mathrm{~kJ} \mathrm{~mol}^{-1}\right)$} \\
\hline & & & & $303 \mathrm{~K}$ & $308 \mathrm{~K}$ & $313 \mathrm{~K}$ \\
\hline 83.9 & 245.6 & 53.04 & 19.61 & 9.77 & 8.32 & 6.71 \\
\hline
\end{tabular}
under microwave irradiation

\section{CONCLUSIONS}

In this study, $\beta$-carotene was desorbed from AABent saturated with different loading concentrations under microwave irradiation at four differ- ent temperatures. The profile describing desorption of $\beta$-carotene from the bentonite adsorbent demonstrated both rapid and slow stages. The experimental data for the desorption kinetics correspond- 
ed well with the predictions of a first-order, twocomponent, three-parameter model.

The activation energies of $\beta$-carotene desorption for the rapid and slow desorption processes were 19.61 and $53.04 \mathrm{~kJ} \mathrm{~mol}^{-1}$, respectively. The activation energies depended on the adsorbent properties and the experimental conditions (microwave irradiation).

The partition of $\beta$-carotene molecules between the liquid phase and the adsorbent was fitted to the Langmuir and Freundlich models. Thermodynamic studies revealed that desorption of $\beta$ carotene from the bentonite adsorbents was nonspontaneous and endothermic in nature.

Acknowledgements. This work was supported by the Ministry of Education and Science of the Republic of Serbia (Project number 172015).

\section{REFERENCES}

[1] Y. Yuan, Y. Gao, L. Mao, J. Zhao, Optimization of conditions for the preparation of $\beta$-carotene nanoemulsions using response surface methodology, Food Chem., 107, 1300 (2008).

[2] A. Sanches-Silva, T. G. Albuquerque, P. Finglas, T. Ribeiro, A. Valente, E. Vasilopoulos, A. Trichopoulou, I. Alexieva, N. Boyko, C. E. Costra, O. Hayran, M. Jorjadze, L. Kaprelyants, D. Karpenko, L. F. D'Antuoonom, H. S. Costaa, Carotenoids, vitamins (A, $\mathrm{B}_{2}, \mathrm{C}$, and $\left.\mathrm{E}\right)$, and total folate of traditional foods from Black Sea Area countries, J. Sci. Food Agric., 93, 3545-3557 (2013).

[3] S. C. Kheok, E. E. Lim, Mechanism of palm oil bleaching by montmorillonite clay activated at various acid concentrations, J. Am. Oil Chem. Soc., 59, 129-131 (1982).

[4] E. Srasra, F. Bergaya, H. van Damme, N. K. Arguib, Surface properties of an activated bentonite - decolorization of rapeseed oil, Appl. Clay Sci., 4, 411-421 (1989).

[5] P. Falaras, I. Kovanis, F. Lezou, G. Seiragakis, Cottonseed oil bleaching by acid-activated montmorillonite, Clay Miner., 34, 221-232 (1999).

[6] G. E. Christidis, S. Kosiari, Decolorization of vegetable oils: A study of the mechanism of adsorption of $\beta$ carotene by an acid-activated bentonite from Cyprus, Clays Clay Miner., 51(3), 327-333 (2003).

[7] M. H. Ma, Ch. I. Lin, Adsorption kinetics of $\beta$-carotene from soybean oil using regenerated clay, Sep. Purif. Technol., 39, 201-209 (2004).

[8] E. Sabah, M. Çinar, M. S. Çelik, Decolorization of vegetable oils: Adsorption mechanism of $\beta$-carotene on acidactivated sepiolite, Food Chem., 100, 1661-1668 (2007).

[9] M. Muhammad, T. S. Y. Choong, T. G. Chuah, R. Yunus, Desorption of $\beta$-carotene from mesoporous carbon-coated monolith: Isotherm, kinetics and regeneration studies, Chem. Eng. J., 173, 474-479 (2011).

[10] M. Huang, Y. Xu, Q. Lv, Q. Ren, Separation and purification of $\beta$-carotene from chlorophyll factory residues., Chem. Eng. Technol., 31(6), 922-927 (2008).

[11] Z. Wu, Ch. Li, Kinetics and thermodynamics of $\beta$ carotene and chlorophyll adsorption onto acid-activated bentonite from Xinjiang in xylene solution, $J$ Hazard. Mater., 171, 582-587 (2009).

[12] M. Muhammad, T. S. Y. Choong, T. G. Chuah, R. Yunus, Y. H. T. Yap, Adsorption of $\beta$-carotene onto mesoporous carbon coated monolith in isopropyl alcohol and $n$-hexane solution: Equilibrium and thermodynamic study, Chem. Eng. J., 164, 178-182 (2010).

[13] S. Petrović, Lj. Rožić, Z. Vuković, T. Novaković, D. Stanisavljev, Response surface optimization for activation of bentonite with microwave irradiation, Clays Clay Miner., 60(1), 32-39 (2012).

[14] J. A. Menendez, A. Arenillas, B. Fidalgo, Y. Fernandez, L. Zubizrreta, E. G. Calvo, J. M. Bermudez, Microwave involving carbon materials, Fuel Process Technol., 91, $1-8$ (2010).

[15] J. Li, Y. G. Zu, Y. J. Fu, Y. C. Yang, S. M. Li, Z. N. Li, M. Wink, Optimization of microwave-assisted extraction of triterpene saponins from defated residue of yellow horn (Xanthoceras sorbifolia Bunge) kernel and evaluation of its antioxidant activity, Innov. Food Sci. Emerg., 11, 637-643 (2010).

[16] G. Zhang, M. Hu, L. He, P. Fu, L. Wang, J. Zhou, Optimization of microwave-assisted enzymatic extraction of polyphenols from waste peanut shells and evaluation of its antioxidant and antibacterial activities in vitro, Food Bioprod. Process., 91, 158-168 (2013).

[17] B. Legras, I. Polert, M. Thomas, L. Estel, About using microwave irradiation in competitive adsorption processes, Appl. Therm. Engi., 57, 164-171 (2013).

[18] R. Cherbanski, E. Molga, Intensification of desorption processes by use of microwaves: An overview of possible applications and industrial perspectives, Chem. Eng. Process., 48(1), 48-58 (2009).

[19] S. Ramesh, B. S. Jai Prakash, Y. S. Bhat, Enhancing Brønsted acid site activity of ion-exchanged montmorillonite by microwave irradiation for ester synthesis, Appl. Clay Sci., 48, 159-163 (2010).

[20] Lj. Rožić, T. Novaković, S. Petrović, Modelling and optimization process parameters of acid activation of bentonite by response surface methodology, Appl. Clay Sci., 48, 154-158 (2010).

[21] E. P. Barrett, L. G. Joyner, P. H. Halenda, The determination of pore volume and area distributions in porous substances. I. Computations from nitrogen isotherms, $J$ Am. Chem. Soc., 73, 373-380 (1951).

[22] F. Rouquerol, J. Rouquerol, K. Sing, Adsorption by powers and porous solids. In: Principles, Methodology and Applications, Academic Press, London, 1999, pp. 18-21.

[23] M. D. Johnson, W. J. Weber, Rapid prediction of longterm rates of contaminant desorption from soils and sediments, Environ. Sci. Technol., 35, 427-433 (2001).

[24] R. A. K. Rao, M. A. Khan, B. H. Hameed, Sorption/desorption studies on some natural minerals for the removal of toxic organic pollutants from aqueous solution, Chem. Eng. J., 152, 421-427 (2009).

[25] T. W. Weber, R. K. Chakkravorti, Pore and solid diffusion models for fixed bed adsorbers, AIChEJ, 20, 218228 (1974).

[26] I. A. W. Tan, B. H. Hammed, A. L. Ahmad, Equilibrium and kinetic studies on basic dye adsorption by oil palm fiber activated carbon, Chem. Eng. J., 127, 111-119 (2007). 